\title{
Export of dissolved organic matter from a mangrove swamp ecosystem: evidence from natural fluorescence, dissolved lignin phenols, and bacterial secondary production
}

\author{
Mary Ann Moran, Richard J. Wicks, Robert E. Hodson \\ Department of Microbiology and Institute of Ecology, University of Georgia, Athens, Georgia 30602, USA
}

\begin{abstract}
Export of dissolved organic matter (DOM) from an island mangrove swamp was traced and quantified by analysis of dissolyed lignin-derived humic substances and naturally fluorescing compounds. Concentrations of both lignin phenols and fluorescent compounds indicated the tidallymediated movement of DOM offshore from the swamp to distances at least $1 \mathrm{~km}$ seaward. Laboratory studies documented the formation of significant amounts of DOM from degrading mangrove leaves, about $20 \%$ of which was highly-fluorescent humic substances. At the $1 \mathrm{~km}$ station, vascular plantderived material was calculated to account for about $10 \%$ of the total DOM, based on simple mixing models. A correlation between apparent concentrations of vascular plant-derived DOM and rates of bacterial secondary production suggests that some components of exported DOM are available for bacterioplankton growth in offshore environments.
\end{abstract}

\section{INTRODUCTION}

The production of bacterial biomass from dissolved organic matter (DOM) is an important step in carbon and energy flow through marine environments, and potentially serves as the mechanism by which dilute dissolved organics become available to metazoan trophic levels (Azam et al. 1983). In estuaries and coastal waters, the DOM available to fuel bacterial production may be either of marine origin, derived primarily from in situ activities of planktonic organisms, or it may be of terrestrial origin, transported to the marine environment via rivers and coastal wetlands. The relative importance of organic matter of terrestrial origin to carbon budgets of coastal marine systems has been an important subject of study for several decades (Teal 1962, Hopkinson 1985, Twilley 1985, Flores-Verdugo et al. 1987, Peterson \& Howarth 1987, Alongi et al. 1989), but has not been definitively resolved for most systems. However, it has been demonstrated recently that in open ocean water, terrestrially-derived organic matter accounts for at least $10 \%$ of the marine humic material and about $0.5 \%$ of the total DOM (Meyers-Schulte \& Hedges 1986).
One approach to determining the origin of DOM in coastal sea water is the identification and quantification of unequivocally terrestrially-derived compounds in the bulk DOM pool. The availability of compounds to serve as terrestrial tracers is somewhat limited, as a large fraction of the DOM pool is chemically uncharacterized (Thurman 1985) and many biological and physical processes are shared between marine and terrestrial environments. However, lignin, a component of the structural tissue of vascular plants (Sarkanen \& Ludwig 1971), has its origin only in terrestrial ecosystems and coastal wetlands. Thus, identification of characteristic lignin-derived phenols in marine DOM unambiguously demonstrates the presence of compounds advected from vascular plant-dominated environments (Meyers-Schulte \& Hedges 1986, Hedges et al. 1988, Moran et al. 1991).

Another potential tracer of terrestrially-derived DOM is naturally fluorescing dissolved humic material. As noticed first by Kalle (1963), sea water exposed to ultraviolet light emits fluorescence with a peak wavelength of $460 \mathrm{~nm}$, presumably due to dissolved humic substances. As phytoplankton-derived DOM does not fluoresce strongly at this wavelength, the 
fluorescence is thought to be associated primarily with organic matter of terrestrial origin (Duursma 1974). This extremely rapid and simple method for identifying terrestrially-derived DOM has been used previously, but not extensively, in tracing the fate of terrestrial material in marine ecosystems (Otto 1967, Zimmerman \& Rommets 1974, Willey \& Atkinson 1982, Willey 1984).

In intertidal environments dominated by vascular plants, such as temperate salt marshes and tropical and subtropical mangrove swamps, rates of primary production are among the highest reported for naiural ecosystems, ranging up to $1500 \mathrm{~g} \mathrm{C} \mathrm{m}^{-2} \mathrm{yr}^{-1}$ (Pomeroy \& Wiegert 1981, Mann 1982). Given the proximity of these communities to coastal waters and the intermittent tidal flooding, the possibility of significant outwelling of dissolved organic matter from such intertidal vascular plant-dominated environments is evident. However, not only the magnitude of export of DOM but its biological availability, that is, whether or not it is of sufficient quality to subsidize the productivity of marine food webs in adjacent coastal waters, are relevant considerations for determining the system-level interactions between vascular plant-dominated intertidal systems and adjacent planktonic environments.

In this paper, we investigate interconnections between a vascular plant-dominated system and adjacent waters by quantifying DOM export from a red mangrove (Rhizophora mangle) swamp and measuring associated rates of bacterial secondary production. The Crab Cay swamp (Berry Islands, the Bahamas) is a small island community in an otherwise open-water marine ecosystem. Based on field studies and labora- tory incubations, we demonstrate the use of lignin phenol concentrations and natural fluorescence as tracers of DOM exported from the Crab Cay swamp and examine the relationship between apparent concentrations of vascular plant-derived DOM and rates of bacterial secondary production within the mangrove swamp and in surrounding coastal waters.

\section{METHODS}

Sample collection. Water collections were made in October 1989 at 3 sites in the Crab Cay vicinity accessed by small boat from the RV 'Gyre'. Station 1 was located in the mangrove swamp, $300 \mathrm{~m}$ interior from the mouth of the mangrove creek. Station 2 was located in a seagrass (Thalassia testudinum) bed adjacent to the mangrove swamp, $50 \mathrm{~m}$ outside the mouth of the creek. Station 3 was located $1 \mathrm{~km}$ offshore from the mangrove creek mouth (Fig. 1)

On 5 d during October 18 through October 26, 1989, the 3 sites were sampled at slack high tide and slack low tide (total of 30 samples) for measurement of concentrations of several components of DOM. We collected 50 I of water from each site in acid-washed Nalgene carboys and immediately returned the carboys to the ship for processing. A 11 subsample was filtered sequentially through an ashed Whatman GF/F filter and an acidwashed $(10 \% \mathrm{HCl}) 0.2 \mu \mathrm{m}$ pore-size Nuclepore filter and immediately frozen in a Nalgene bottle for later fluorescence measurements. Of the remaining water, $38 \mathrm{l}$ were filtered sequentially through ashed large-

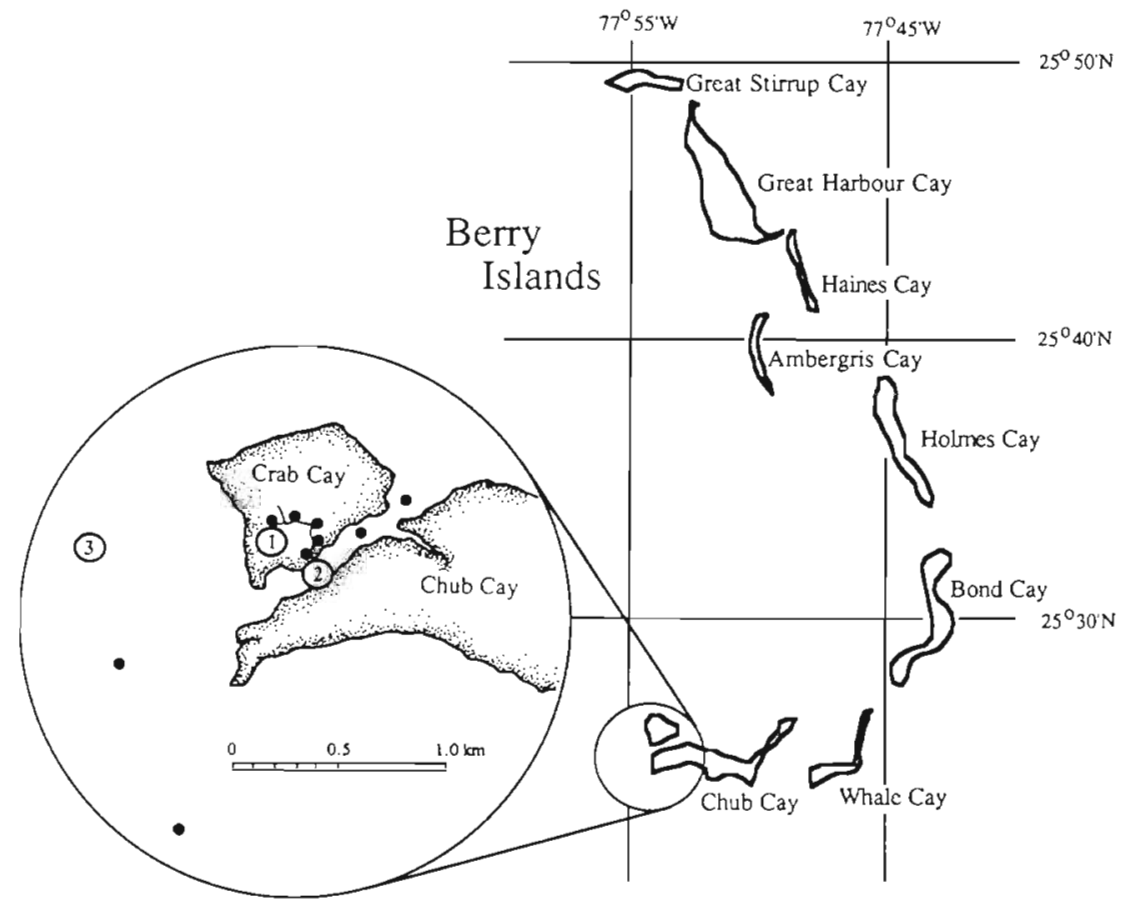

Fig. 1 Berry Islands, the Bahamas, and Crab Cay study site (inset). Numbers indicate location of the 3 main stations sampled in 1989 and 1990. Closed circles indicate supplementary sites sampled for natural fluorescence and rates of bactenal secondary production in 1990 
diameter (293 mm) Gelman AE and Whatman GF/F glass fiber filters, and then acidified to $\mathrm{pH} 2$ with $6 \mathrm{~N} \mathrm{HCl}$ in preparation for isolation of humic substances. Two $1 \mathrm{ml}$ subsamples were removed and frozen in ashed glass vials for later determination of dissolved organic carbon (DOC) concentration by high temperature combustion (Shimadzu TC500).

During a second cruise to the Crab Cay mangrove swamp in October 1990,30 water samples were collected for simultaneous measurement of natural fluorescence and rates of bacterial secondary production. On October 21 and 22, 11 water samples were collected at high, mid, and low tide at Stations 1, 2 and 3 (18 samples). On October 24, 12 additional $1 \mathrm{l}$ samples were collected from sites within the mangrove swamp creek, over the seagrass bed, and up to $3 \mathrm{~km}$ offshore. On all sampling days, water was immediately returned to the ship for processing (see below).

Humic substances isolation. Humic substances were isolated from the 30 samples collected in 1989 by pumping $38 \mathrm{l}$ of water at a rate of $50 \mathrm{ml} \mathrm{min}^{-1}$ through a 2.2 by $40 \mathrm{~cm}$ column of Amberlite XAD- 8 resin which previously had been cleaned sequentially with ether, acetonitrile, methanol and ether (24 h soxhlet extraction for each solvent) and prepared with repeated rinses of $\mathrm{HCl}, \mathrm{NaOH}$, and distilled/deionized water (Aiken 1985, Moran \& Hodson 1990a). The XAD-8 resin (with adsorbed humic substances) was emptied from the column into a Nalgene bottle and stored at $4{ }^{\circ} \mathrm{C}$. Following the cruise, resins were poured back into columns and humics were eluted with $200 \mathrm{ml} 0.1 \mathrm{~N}$ $\mathrm{NaOH}$ followed by $100 \mathrm{ml}$ distilled water. Sodium ions were removed from the humic eluant by pumping through a 2.2 by $40 \mathrm{~cm}$ column of Bio Rad AG-MP50 cation exchange resin, previously cleaned with methanol and prepared with repeated rinses of $\mathrm{NH}_{4} \mathrm{OH}$ and $\mathrm{HCl}$. Humic substances were concentrated by rotary evaporation, freeze-dried, and stored frozen. Carbon content of the humics was determined on a PerkinElmer 240C CHN analyzer.

Carbon budgets were calculated for 14 samples to check for quantitative processing and to determine the efficiency of humic substance recovery from the XAD-8 resin. Seawater eluant from the XAD-8 column was collected and analyzed for DOC concentration. Budgets were calculated by summing the carbon per unit volume of this eluant (non-humic carbon) and the humic carbon recovered per unit volume of sea water processed. This sum was compared to the DOC content per volume of original seawater sample. Carbon recovery averaged $92 \pm 6 \%$.

Lignin phenol analysis. Lignin-derived compounds in humic substances extracted from the 1989 samples were quantified by gas chromatographic analysis of cupric oxide oxidation products (Hedges \& Ertel 1982,
Ertel et al. 1984). The oxidation procedure involved reacting 10 to $25 \mathrm{mg}$ of freeze-dried humic substances with alkaline cupric oxide for 3 h at $170^{\circ} \mathrm{C}$ to produce a suite of 8 simple phenols: vanillic acid, vanillin, and acetovanillone ( $\mathrm{V}$ phenols); syringic acid, syringealdehyde, and acetosyringone (S phenols); and ferulic acid and $\rho$-coumaric acid ( $C$ phenols). Three additional phenols ( $\rho$-hydroxybenzoic acid, $\rho$-hydroxybenzaldehyde, and $\rho$-hydroxyacetophenone; $P$ phenols) potentially have both lignin and non-lignin sources (Hedges \& Parker 1976) and thus were not included in the analyses. Phenols were extracted from the oxidation mixture with ether and converted to trimethylsilyl derivatives, and quantification of lignin phenols was carried out on an HP 5890 gas chromatograph. Samples were analyzed both on a Supelco SE-30 (100\% dimethyl polysiloxane) and a J \& W DB-1701 (86\% dimethyl and $14 \%$ cyanopropylphenyl polysiloxane) silica capillary column (Hedges et al. 1988, Moran et al. 1991). Non-lignin oxidation products frequently coeluted with syringealdehyde, $\rho$-coumaric acid, and ferulic acid on the SE-30 column; corrections were made for concentrations of these compounds based on the DB-1701 column after normalizing to $\rho$-hydroxybenzoic acid concentrations

To check reproducibility of the oxidation procedure, a second oxidation was carried out for 2 samples. Lignin phenol concentrations (sum of 8 unambiguous phenols) agreed within $90 \%$ of the original values for both re-oxidized samples. To check reproducibility of quantification by gas chromatography, a second injection and analysis of the oxidation mixture was performed for 6 samples. Lignin phenol concentrations agreed within $83 \pm 2.4 \%$.

Natural fluorescence measurements. Fluorescence of water samples collected in 1989 (0.2 $\mu \mathrm{m}$-filtered and stored frozen until assayed) and in 1990 (0.2 $\mu \mathrm{m}$-filtered and assayed within $8 \mathrm{~h}$ of collection) was determined on a Turner Fluorometer 111 using a $365 \mathrm{~nm}$ excitation filter and a $460 \mathrm{~nm}$ sharp cut secondary filter. Five-ml disposable test tubes which had been matched for similarity in optical properties were used as cuvettes. Fluorescence was measured against an artificial sea water (ASW) blank made with distilled/deionized water. Relative fluorescence values were expressed as units of the highest sensitivity setting (30X) on the fluorometer, rather than based on an arbitrary quinine bisulfate standard as previously described (Kalle 1963, Willey \& Atkinson 1982).

Humic carbon standards were made by dissolving recovered humic substances from samples collected in 1989 in $1 \mathrm{ml} 0.05 \mathrm{~N} \mathrm{NaOH}$ in a $100 \mathrm{ml}$ volumetric flask and bringing the solutions to volume with ASW. Final $\mathrm{pH}$ of the standards was 7.0. Because of mass requirements for lignin phenol and $\mathrm{CHN}$ analyses, sufficient 
humic material for making standard solutions was available for only a limited number of samples. Standard solutions with concentrations varying from 0.11 to $0.67 \mathrm{mg} \mathrm{C} \mathrm{l}^{-1}$ were made from the humic substances isolated from the October 26, 1989, low tide sample at Station 2. Standard solutions at a concentration of 0.33

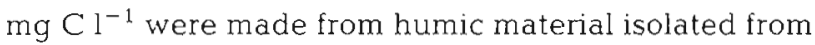
2 samples from Station 1 (October 20, low tide; October 26, low tide), 1 sample from Station 2 (October 23, low tide), and 2 samples from Station 3 (October 26, high tide; October 26, low tide). These humic standards were used to check for a linear relationship between humic substances concentration and fluorescence and to compare relative fluorescence of humics collected at the 3 stations.

Bacterial production measurements. Rates of bacterial secondary production in water samples collected in 1990 were determined by measuring incorporation of ${ }^{3} \mathrm{H}$ ]leucine into bacterial protein (Kirchman et al. 1986). Immediately after returning to the ship (within $30 \mathrm{~min}$ of sample collection), four $5 \mathrm{ml}$ aliquots from each of the samples were placed in sterile, combusted $20 \mathrm{ml}$ scintillation vials. To one vial, which served as the killed control, $250 \mu \mathrm{l} 5 \mathrm{~N} \mathrm{NaOH}$ and $500 \mu \mathrm{l} 100 \%$ trichloroacetic acid (TCA) were added, and $\left[{ }^{3} \mathrm{H}\right]$ leucine was then added to all vials at a final concentration of 10 nM. After a $1 \mathrm{~h}$ incubation period, $\mathrm{NaOH}$ was added to the live incubations. After $15 \mathrm{~min}$ at room temperature, TCA was added to live incubations and all vials were placed in a $95^{\circ} \mathrm{C}$ water bath for $30 \mathrm{~min}$. Vials were placed on ice for $10 \mathrm{~min}$ after removal from the water bath and contents were filtered through $0.22 \mu \mathrm{m}$ poresize Millipore filters. Filters were washed 3 times with cold 5\% TCA and once with cold $80 \%$ ethanol (Wicks \& Robarts 1988j and then assayed for radioactivity.

A factor for converting leucine incorporation data into bacterial carbon production was determined aboard ship by the empirical method of Kirchman \& Hoch (1988). A seawater culture $(450 \mathrm{ml}$ filter-sterilized mangrove swamp water plus $50 \mathrm{ml}$ whole mangrove swamp water) was stirred slowly at room temperature for $8 \mathrm{~h}$. At $0,2,4,6$, and $8 \mathrm{~h}$ after the culture was established, four $5 \mathrm{ml}$ subsamples were removed for $\left[{ }^{3} \mathrm{H}\right]$ leucine incorporation measurements. Simultaneously, two $10 \mathrm{ml}$ subsamples were removed and stored at $4{ }^{\circ} \mathrm{C}$ in $2 \%$ (final concentration) formaldehyde in plastic scintillation vials. Changes in bacterial biomass during the course of the $8 \mathrm{~h}$ incubation were later determined by epifluorescence microscopy of the fixed samples. Average number of cells per milliliter at each time point was determined by counting acridine orange-stained cells $(0.01 \%)$ filtered onto black $0.2 \mu \mathrm{m}$ pore-size Nuclepore filters (Hobbie et al. 1977). Average per-cell biovolume at each time point was determined by photographing fluorescent cells and project- ing slides onto a paper screen. Cell outlines were traced and linear dimensions converted to volume based on the average of 2 formulas for cell shape (prolate spheroid shape and capped cylinder shape; Moran \& Hodson 1989). Projected slides of fluorescent beads of known diameter (Polysciences Inc.) were used for calibration. Bacterial biovolume was converted to carbon assuming $2.2 \times 10^{-13} \mathrm{~g} \mathrm{C}^{-3} \mathrm{~m}^{-3}$ (Bratbak \& Dundas 1984). The conversion factor was calculated by the integrative method of Riemann et al. (1987) and determined to be $7.2 \mathrm{ng}$ bacterial $\mathrm{C}$ (pmole $\left.\right|^{3} \mathrm{H}$ lleucine $)^{-1}$ incorporated.

Laboratory incubations. Formation of dissolved humic substances, lignin phenols, and naturally-fluorescing compounds during the degradation of red mangrove leaves was followed in laboratory incubations. Senescing (yellow-colored) leaves were collected from mangrove trees in October 1989 , dried at $50^{\circ} \mathrm{C}$, ground to $<425 \mu \mathrm{m}$ in a Wiley Mill, and incubated in the dark at room temperature in aerated 11 flasks containing $850 \mathrm{ml}$ ASW and $5 \mathrm{ml}$ bacterial inoculum (prepared by 20 -fold concentration over a $0.2 \mu \mathrm{m}$ pore-size Nuclepore filter of $1.0 \mu \mathrm{m}$ filtered water). Inorganic nutrients $[5 \mu \mathrm{M} \mathrm{N}$ (nitrate plus nitrite) and $1 \mu \mathrm{M}$ phosphate] were added initially and at bi-weekly intervals. After 2, 4 and $8 \mathrm{wk}$ of incubation, 3 replicate flasks were harvested. Contents of the flasks were filtered sequentially through ashed Whatman GF/F glass fiber filters and $0.2 \mu \mathrm{m}$ pore-size Rainin nylon filters. Filtrates were stored frozen until humic substance isolation on an XAD-8 resin and lignin phenol analysis (see above). Natural fluorescence was measured for total DOM recovered from the incubations and for the non-humic fraction of DOM (after passage through XAD-8 resin). Fluorescence of the humic fraction was calculated by difference.

\section{RESULTS}

\section{Field studies}

Four measures of dissolved organic matter concentrations were made for each sample collected in 1989: total DOC concentration, humic carbon concentration, lignin phenol concentration, and natural fluorescence intensity (Table 1). DOC concentrations varied 2 -fold from an average of $1.1 \mathrm{mg} \mathrm{l}^{-1}$ in water $1 \mathrm{~km}$ offshore from the Crab Cay mangroves (Station 3) to $2.3 \mathrm{mg} \mathrm{l}^{-1}$ in water in the mangrove swamp (Station 1) at low tide. Humic carbon varied 5 -fold in concentration from 0.1 $\mathrm{mg} \mathrm{l}^{-1}$ at Station 3 to $0.5 \mathrm{mg} \mathrm{l}^{-1}$ at Station 1 at low tide, accounting for 9 to $22 \%$ of the bulk DOC pool. Average lignin phenol concentrations ranged from $0.6 \mu \mathrm{M} \mathrm{l}^{-1}$ at Station 3 to $6.4 \mathrm{\mu g} \mathrm{l}^{-1}$ at Station 1 at low tide. Lignin phenols accounted for 0.03 to $0.23 \%$ of the total DOC. 
Table 1. Concentrations of DOC, humic carbon, and dissolved lignin phenols, and intensity of natural fluorescence in water samples from Crab Cay in October 1989. Site 1 is a mangrove (Rhizophora mangle) swamp creek, site 2 is a seagrass (Thalassia testudinum) bed, and site 3 is an open water area $1 \mathrm{~km}$ offshore from the mangrove swamp island. Values are the mean of 5 sequential samples $( \pm 1 \mathrm{SE})$ unless otherwise noted

\begin{tabular}{|c|c|c|c|c|}
\hline Location & $\begin{array}{c}\mathrm{DOC} \\
\left(\mathrm{mg} \mathrm{l}^{-1}\right)\end{array}$ & $\begin{array}{l}\text { Humic C } \\
\left(\mathrm{mg} \mathrm{l}^{-1}\right)\end{array}$ & $\begin{array}{l}\text { Lignin phenols } \\
\left(\left.\mu g\right|^{-1}\right)\end{array}$ & $\begin{array}{c}\text { Fluorescence } \\
\text { (fluorometer units) }\end{array}$ \\
\hline \multicolumn{5}{|l|}{ Low Tide } \\
\hline Site 1 & $2.27 \pm 0.08$ & $0.48 \pm 0.02$ & $6.39 \pm 0.93$ & $260 \pm 16$ \\
\hline Site 2 & $1.55 \pm 0.08^{c}$ & $0.27 \pm 0.05$ & $3.24 \pm 1.47$ & $113 \pm 27$ \\
\hline Site 3 & $1.10 \pm 0.10$ & $0.14 \pm 0.01^{a}$ & $0.61 \pm 0.07$ & $26 \pm 5^{c}$ \\
\hline \multicolumn{5}{|l|}{ High Tide } \\
\hline Site 1 & $1.13 \pm 0.03^{b}$ & $0.16 \pm 0.01^{c}$ & $0.84 \pm 0.16$ & $20 \pm 4$ \\
\hline Site 2 & $1.10 \pm 0.08^{b}$ & $0.16 \pm 0.01$ & $0.75 \pm 0.12$ & $16 \pm 6$ \\
\hline Site 3 & $1.08 \pm 0.13^{\mathrm{a}}$ & $0.13 \pm 0.01^{c}$ & $0.55 \pm 0.09$ & $9 \pm 3$ \\
\hline
\end{tabular}

and 0.1 to $1.3 \%$ of humic carbon concentrations Natural fluorescence of DOM varied 26-fold, ranging from 9 units offshore at Station 3 at high tide to 260 units within the mangrove swamp at low tide.

All 4 categories of DOM (i.e. total DOC, humic C, lignin phenols, fluorescent compounds) varied with station and tidal stage according to a similar pattern (Table 1). Two-way ANOVAs (station by tidal stage) indicated that concentrations were highest inside the mangrove swamp at Station 1, intermediate at Station 2 (averaging $62 \%$ of swamp values), and lowest offshore at Station 3 (averaging $34 \%$ of swamp values and $50 \%$ of seagrass values) ( $p<0.01$ for all 4 parameters). Furthermore, concentrations of each DOM category also differed significantly between tidal stages, being higher at low tide than at high tide $(p<0.01)$. As evidenced by significant ANOVA interaction effects (station by tidal stage; $p<0.01$ for all parameters), the disparity in concentration between stations was more pronounced at low tide than at high tide. Concentrations of the 4 categories of DOM at low tide at Station 3 averaged $24 \%$ of concentrations at Station 1 , while at high tide, concentrations at Station 3 averaged $55 \%$ of Station 1. Likewise, concentrations of the 4 DOM categories in water over the seagrass community at Station 2 averaged $72 \%$ of mangrove swamp values at low tide but $92 \%$ at high tide. The low and relatively uniform concentrations of all DOM categories at all sites during high tide are likely the result of movement of offshore water over the seagrass beds and into the mangroves during tidal flooding, and subsequent equalizing of dissolved organic matter concentrations throughout the study area to values typical of oceanic water. The high and non-uniform concentrations of all 4 DOM categories at low tide are likely the result of inputs of organic matter from the mangrove swamp and seagrass beds to water resident in these systems.
The 4 indices of dissolved organic matter concentration were positively related, as expected from the similar patterns observed across stations and tidal stages. Natural fluorescence of seawater was positively correlated with DOC concentration $(r=0.92, p<0.01)$ and humic $C$ concentration ( $r=0.96, p<0.01$ ). Likewise, dissolved lignin phenol concentrations were positively correlated with DOC ( $\mathrm{r}=0.89, \mathrm{p}<0.01)$ and humic $\mathrm{C}(\mathrm{r}=0.89, \mathrm{p}<0.01)$ (Fig. 2), and concentrations of lignin phenols and natural fluorescence were positively correlated with one another $(\mathrm{r}=0.82 ; \mathrm{p}<0.01)$.

Rates of bacterial secondary production in water
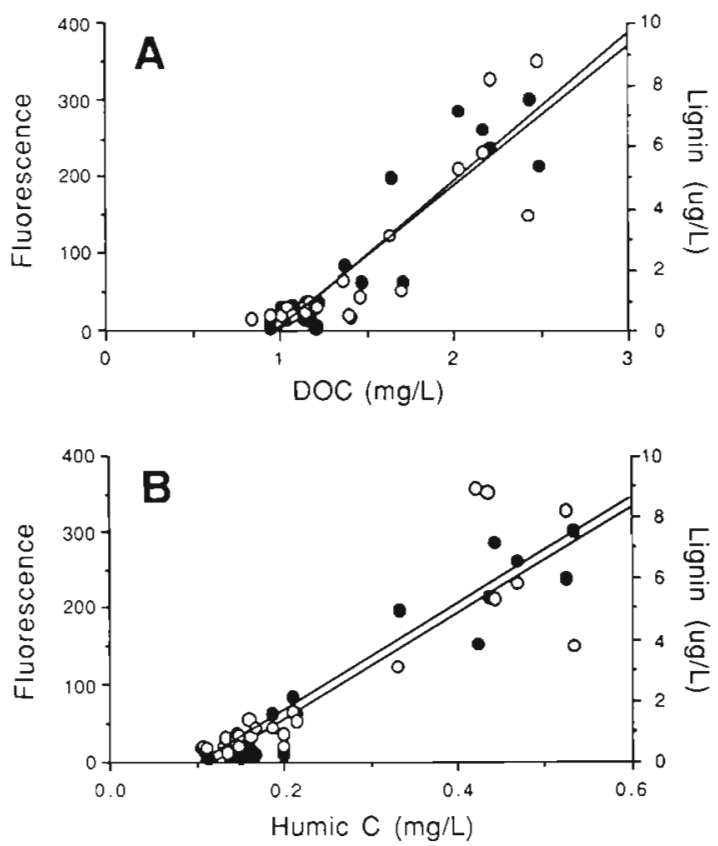

Fig. 2. Regressions of natural fluorescence (closed circles) and lignin phenol concentrations (open circles) in seawater samples against $\operatorname{DOC}(\mathrm{A})$ and humic $C$ concentrations (B) 
samples collected in the mangrove swamp and offshore areas varied over 60 -fold, from 8 to $483 \mathrm{ng}$ bacterial $\mathrm{C}$ $1^{-1} h^{-1}$ Production was highest in water from inside the mangrove swamp and in the seagrass bed and lowest in water collected offshore. Rates of bacterial secondary production were positively correlated with the concentration of naturally fluorescing compounds, the single DOM component measured simultaneously with bacterial production in these samples (Fig. 3; $r=0.69$, $\mathrm{p}<0.01$ ).

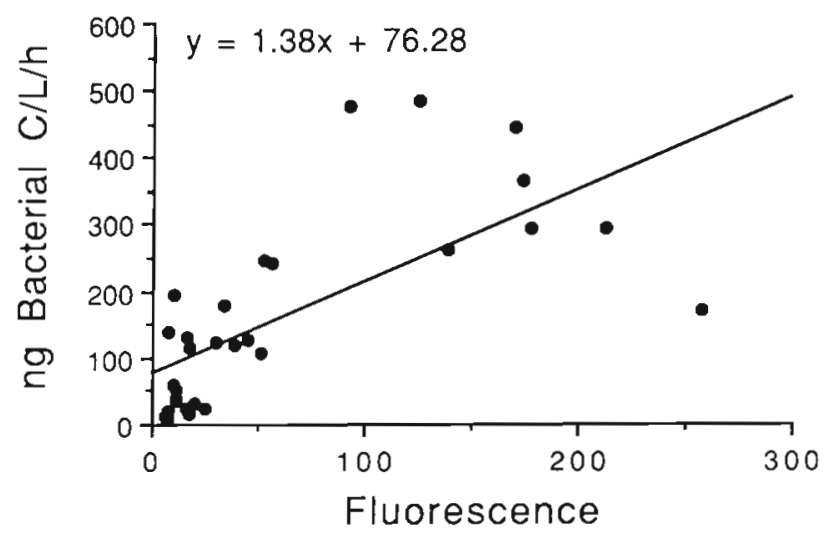

Fig. 3. Regression of rates of bacterial secondary production against natural fluorescence of sea water

\section{Humic standards}

Fluorescence of humic substances isolated from Station 2 (October 26, 1989 sample, low tide) was measured over a range of concentrations which brackets the natural humic substances concentrations found in our seawater samples $\left\{0.11\right.$ to $0.67 \mathrm{mg} \mathrm{Cl}^{-1}$ ). Fluorescence was linearly related to humic carbon concentration throughout this range $\left(\mathrm{r}^{2}=0.995\right)$. We compared the relative fluorescence, on a carbon basis, of humic standards prepared with material from the 3 stations (Fig. 4). Humic substances from the mangrove swamp fluoresced most strongly, while humics from the seagrass bed fluoresced at $88 \%$ of the intensity measured

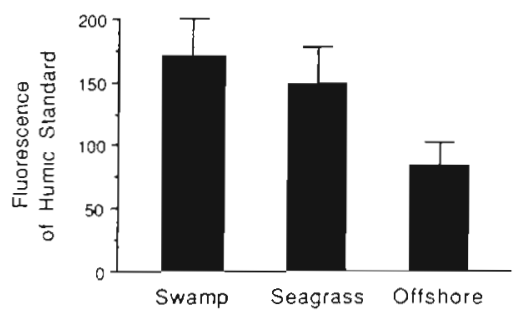

Fig. 4. Fluorescence of dissolved humic substances collected from Station 1 (Swamp), Station 2 (Seagrass), and Station 3 (Offshore) expressed for a $1 \mathrm{mg} \mathrm{C \textrm {C } ^ { - 1 }}$ solution. Units are Turner Fluorometer 111 readings at the high sensitivity (30X) setting. Bars represent. $1 \mathrm{SE}(\mathrm{n}=2)$ for mangrove swamp humics, and humics from offshore were only half as fluorescent ( $49 \%)$ as mangrove swamp humics. Thus compounds which absorb at $365 \mathrm{~nm}$ and fluoresce at $460 \mathrm{~nm}$ made up a greater percentage of the dissolved humic substances in the vascular plant-dominated system than in humics collected in offshore areas.

\section{Laboratory studies}

After 2 wk of degradation by natural marine bacterial assemblages in laboratory incubations, $88 \%$ of the initial biomass of red mangrove leaves remained as particulate material, $8 \%$ had been solubilized to DOC, and the remainder $(4 \%)$ was presumably transformed to $\mathrm{CO}_{2}$ and free-living microbial biomass. DOC therefore accounted for $67 \%$ of the total transformed material, and a significant fraction of DOC was in the form of humic substances (23\%; Table 2).

After 8 wk of decomposition, an additional $6 \%$ of the particulate material was degraded. DOC accounted for a gradually decreasing percentage of the total accumulated transformation products (Table 2), suggesting either mineralization of DOC produced earlier in the incubation or formation of relatively less DOC as a percentage of degradation products with time. Humic substances also declined in importance $(17 \%$ of the DOC pool by Week 8), which likewise may represent the transformation of humics to other forms (non-humic compounds, microbial biomass, or $\mathrm{CO}_{2}$ ) or a decreasing rate of formation of dissolved humic substances from leaf material relative to total DOC formation.

Natural fluorescence of total DOM derived from laboratory-degraded mangrove leaves ranged from 11 to 20 units for a $1 \mathrm{mg} \mathrm{C} 1^{-1}$ solution. The bulk of fluorescence $(71 \%)$ was associated with the humic fraction of DOC and humics became increasingly fluorescent with age (Table 2). As humic carbon accounted for only $21 \%$ of the total DOC, its relative fluorescence was substantially higher than that of non-

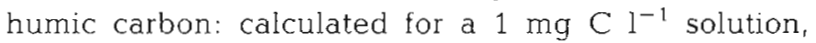
fluorescence of humic carbon isolated from the incubations averaged 56 units, while fluorescence of nonhumic carbon averaged only 5 units.

\section{DISCUSSION}

While humic substances and other components of the DOM pool are known to have both marine and terrestrial sources, dissolved lignin derivatives originate only in terrestrial, intertidal, and subtidal environments which support the growth of vascular plants, making lignin phenols particularly useful as unambiguous tracers of vascular plant material in marine systems. In our 
Table 2. Formation of DOM from red mangrove leaves degrading in laboratory incubations. DOM was collected after 2,4 , and 8 wk of degradation $(n=3)$

\begin{tabular}{|c|c|c|c|c|}
\hline Parameter & Units & 2 weeks & 4 weeks & 8 weeks \\
\hline Total transformation ${ }^{a}$ & $\begin{array}{l}\mathrm{mg} \mathrm{C} \\
\% \text { of initial }\end{array}$ & $\begin{array}{c}146 \pm 14 \\
12.4 \pm 1.1\end{array}$ & $\begin{aligned} 197 & \pm 10 \\
16.7 & \pm 0.9\end{aligned}$ & $\begin{array}{l}215 \pm 5 \\
18.1 \pm 0.4\end{array}$ \\
\hline $\mathrm{DOC}$ & $\begin{array}{l}\mathrm{mg} \mathrm{C} \\
\% \text { of initial } \\
\% \text { of transformed }\end{array}$ & $\begin{array}{c}91 \pm 6 \\
8.1 \pm 0.4 \\
64.0 \pm 9.7\end{array}$ & $\begin{aligned} 78 & \pm 7 \\
6.7 & \pm 0.6 \\
40.3 & \pm 5.2\end{aligned}$ & $\begin{aligned} 81 & \pm 13 \\
6.5 & \pm 1.0 \\
38.1 & \pm 6.5\end{aligned}$ \\
\hline Humics & $\begin{array}{l}\mathrm{mg} \mathrm{C} \\
\% \text { of transformed } \\
\% \text { of DOC }\end{array}$ & $\begin{array}{c}21 \pm 1 \\
14.6 \pm 2.4 \\
22.8 \pm 1.6\end{array}$ & $\begin{array}{c}17 \pm 2 \\
8.8 \pm 0.8 \\
22.9 \pm 4.9\end{array}$ & $\begin{array}{c}13 \pm 1 \\
6.2 \pm 0.6 \\
16.8 \pm 1.5\end{array}$ \\
\hline Lignin phenols & $\begin{array}{l}\mu \mathrm{g} \mathrm{C} \\
\% \text { of transformed } \\
\% \text { of DOC }\end{array}$ & $\begin{array}{l}290 \pm 67 \\
0.21 \pm 0.07 \\
0.31 \pm 0.05\end{array}$ & $\begin{array}{l}238 \pm 59 \\
0.12 \pm 0.03 \\
0.32 \pm 0.11\end{array}$ & $\begin{array}{c}159 \pm 33 \\
0.08 \pm 0.02 \\
0.20 \pm 0.03\end{array}$ \\
\hline DOC fluorescence & $\begin{array}{l}1 \mathrm{mg} \mathrm{Cl} \mathrm{Cl}^{-1} \\
\text { solution }\end{array}$ & $10.7 \pm 1.1$ & $15.2 \pm 2.4$ & $19.6 \pm 3.5$ \\
\hline Humics fluorescence & $\begin{array}{l}1 \mathrm{mg} \mathrm{C} \mathrm{l}{ }^{-1} \\
\text { solution }\end{array}$ & $31.5 \pm 2.7$ & $51.1 \pm 2.7$ & $85.3 \pm 8.0$ \\
\hline $\begin{array}{l}\text { Non-Humics } \\
\text { fluorescence }\end{array}$ & $\begin{array}{l}1 \mathrm{mg} \mathrm{C} l^{-1} \\
\text { solution }\end{array}$ & $4.5 \pm 0.6$ & $5.3 \pm 1.0$ & $6.1 \pm 1.0$ \\
\hline $\begin{array}{l}\text { Humics fluorescence } \\
\text { as } \% \text { of Total }\end{array}$ & & $66.9 \pm 4.8$ & $73.3 \pm 1.3$ & $74.2 \pm 0.6$ \\
\hline
\end{tabular}

study area, patterns of lignin phenol concentration suggest a significant input of vascular plant-derived material to sea water while resident in the mangrove swamp, and advective transport of this dissolved material offshore during tidal flushing. Patterns of total DOC and humic C concentrations parallel those of lignin phenols and likewise suggest loading of organic matter into sea water resident in the mangrove swamp. Laboratory incubations corroborate the formation of significant amounts of DOM during the degradation of red mangrove leaves, as well as rapid formation of dissolved humic substances and dissolved lignin phenols. Similar but less pronounced increases in lignin phenols, humic $C_{\text {, }}$ and total DOM observed in water associated with seagrass beds may reflect inputs from the seagrass community itself, advection of DOM from adjacent mangroves, or both.

The source of marine DOM components which fluoresce at $460 \mathrm{~nm}$ has been suggested, like lignin phenols, to be primarily terrestrial; therefore, natural fluorescence may also serve as an indicator of vascular plant-derived DOM in marine systems. Evidence for the terrestrial origin of the bulk of naturally fluorescing compounds comes from Laane \& Koole (1982) who found natural fluorescence and DOC ratios in North Sea estuaries to be consistent with the mixing of highly fluorescent fresh water with less fluorescent sea water, and from Traganza (1969) based on fluorescence spectra obtained from marine algae-dominated samples (algal cultures and blooms). Several lines of evidence from our study suggest that terrestrial (i.e. intertidal vascular plant) sources of fluorescent DOM dominate in this mangrove swamp ecosystem. First, fluorescent DOM was rapidly formed during the degradation of red mangrove leaves in laboratory incubations. Given the relatively high primary productivity of mangrove swamps in general (Lugo \& Snedaker 1974 , Odum \& Heald 1975) and the abundance of detrital mangrove leaves in the sediments and creek water of Crab Cay, the mangrove ecosystem could readily serve as a point source of naturally fluorescing compounds. Second, the decreased fluorescence of humic substances recovered from offshore water compared to mangrove swamp water (Fig. 4) suggests the mixing of fluorescent mangrove-derived humics with marinederived humics which are either less fluorescent or non-fluorescent in nature. Third, slopes of regression lines of natural fluorescence and lignin phenol concentrations against total DOC (Fig. 2a) and humic C (Fig. 2b) do not differ significantly (ANCOVA, based on normalized lignin concentrations and fluorescence values) and the lines have similar $x$-axis intercepts $(1.1 \mathrm{mg}$ $\mathrm{l}^{-1}$ DOC and $0.13 \mathrm{mg} \mathrm{l}^{-1}$ humic C). While more sophisticated methods for measuring fluorescence promise to increase the amount and quality of information extracted from natural fluorescence properties of sea 
water (Cabaniss \& Schuman 1987, Coble et al. 1990), we have found that single excitation/emission measurements are sufficient for gross tracking of export and dilution of vascular plant-derived DOM in a marine system.

The laboratory incubations allowed us to test directly the hypothesis that fluorescence properties are associated primarily with the dissolved humic fraction of DOM (Larson \& Rockwell 1980, Zimmerman \& Rommets 1974). Average fluorescence of a $1 \mathrm{mg} \mathrm{C}^{-1}$ solution of humic carbon was determined to be 11 -fold greater than the fluorescence of non-humic carbon at the same concentration (Table 2). Moreover, the relative fluorescence of humic vs non-humic DOM changed from a 7 -fold difference after 2 wk to a 14 -fold difference after $8 \mathrm{wk}$ (Table 2). This shift was due mainly to increasing fluorescence of the humic fraction of DOM with age, rather than to changes in the nonhumic fraction. Analysis of a natural sample also suggested greater contributions of fluorescent compounds from humic substances than non-humic substances: humics were present at a concentration of $0.21 \mathrm{mg} \mathrm{Cl}^{-1}$ in the October 26, Station 2, low-tide sample and, from the standard curve of humics concentration vs fluorescence prepared from this sample, accounted for $81 \%$ of the total measured fluorescence yet only $15 \%$ of the DOC.

Humic substances recovered from seawater samples were found to fluoresce more strongly than humics formed from degrading mangrove leaves in laboratory incubations: calculations indicate a fluorescence value of 170 units for a $1 \mathrm{mg} \mathrm{Cl}^{-1}$ solution of humics isolated from mangrove swamp creek water (based on 2 standard solutions made from Station 1 humics; Fig. 4), but only 56 units for laboratory-derived mangrove humics at the same concentration (Table 2). This 3-fold greater fluorescence of natural humics may result from: (1) in situ modifications to mangrove-derived DOM by abiotic or biotic processes (e.g. UV light-mediated modifications or biological transformations); (2) additional sources of humics within the swamp which are significantly more fluorescent than mangrove-derived humics; or (3) greater age of DOM in mangrove creek water relative to the laboratory incubations. As humics harvested from laboratory incubations after 8 wk of decomposition were almost 3 -fold more fluorescent than humics harvested after 2 wk, mangrove-derived humics apparently become increasingly fluorescent with age.

The positive correlation between rates of bacterial secondary production and fluorescence indicates that some fraction of mangrove-derived DOM for which fluorescent compounds serve as a tracer is suitable for supporting bacterial growth. Tidal transport of mangrove-derived DOC offshore may thus provide an important source of carbon and nutrients for growth of coastal bacterioplankton, although in a previous study, benthic bacterial production was apparently not stimulated by exported organic matter from mangrove forests (Alongi et al. 1989). The exact role of mangrovederived DOM in the microbial food web of adjacent planktonic environments will depend on at least 2 factors: the quality of exported material (apparently sufficient for supporting bacterial growth in our system) and the magnitude of export, i.e. the percentage of offshore DOM originating in the mangrove system.

We have taken 2 approaches to estimating the contribution of mangrove-derived DOM to offshore water. First, a simple mixing model is used which assumes conservative mixing of terrestrial DOM with marine DOM. In the Crab Cay system, the absence of a significant freshwater source eliminates the complication of possible organic matter precipitation at a freshwater/ seawater interface, making conservative mixing a reasonable assumption. We can calculate the dilution of high-DOM mangrove swamp water (Station 1, low tide) with low-DOM oceanic water necessary to obtain the average measured values in water collected at Station 3 according to the equations:

$$
\begin{gathered}
\text { Dilution Factor }= \\
\left(\mathrm{LP}_{\mathrm{Sta} 1}-\mathrm{LP}_{\mathrm{Sta} 3}\right) /\left(\mathrm{LP}_{\mathrm{Sta} 3}-\mathrm{LP}_{\mathrm{ocean}}\right)+1 \text {, and }
\end{gathered}
$$

Dilution Factor $=\left(F_{\mathrm{Sta}_{1}}-\mathrm{F}_{\mathrm{Sta} 3}\right) /\left(\mathrm{F}_{\mathrm{Sta} 3}-\mathrm{F}_{\mathrm{ocean}}\right)+1,(2)$

where $L P_{\text {Stal }}=$ average concentration of lignin phenols in mangrove swamp water at low tide $(6.39 \mu \mathrm{g}$ $\left.1^{-1}\right) ; L P_{\text {Sta } 3}=$ average concentration of lignin phenols in offshore (Station 3) water $\left(0.58 \mu \mathrm{g} \mathrm{l}^{-1}\right) ; \mathrm{IP}_{\text {ocean }}=$ concentration of lignin phenols in oceanic water (assumed to be 0 ); $F_{\text {Sta1 }}, F_{\text {Sta3 }}$ and $F_{\text {ocean }}=$ average corresponding values of natural fluorescence at these locations (260 units, 18 units, and 0 units, respectively). Results of the mixing models indicate that dilution of mangrove swamp DOM by ocean-derived DOM at Station 3 was 11 -fold based on lignin phenol concentrations, and 14 -fold based on fluorescence. Thus, an average of $8 \%$ of the DOM present at Station 3 was derived from the mangrove swamp. The presence of measurable lignin phenols and fluorescence in the oceanic end member (i.e. with origin outside this mangrove swamp), rather than our assumption of none, would increase the dilution factor calculated from the mixing model and decrease the calculated percent contribution of mangrove-derived DOM to the total DOM at Station 3

The second approach to estimating the contribution of mangrove-derived DOM to offshore water involves a comparison of lignin phenol concentrations in laboratory incubations with those of field samples (Moran \& Hodson 1990b). Lignin phenols accounted for 
$0.28 \pm 0.04 \%$ of DOC in laboratory incubations (aged 2 to $8 \mathrm{wk}, 0.20 \pm 0.02 \%$ of the total DOC at low tide in the mangrove swamp creek, and $0.03 \pm 0.003 \%$ of the total DOC at Station 3 (average of low and high-tide samples). Assuming dilution of mangrove-derived DOC similar to that formed in the laboratory incubations with marine-derived, lignin-free DOC, we calculate that $71 \%(0.20 / 0.28 \times 100)$ of the DOC in the mangrove creek at low tide was vascular plant-derived. Offshore at Station 3, we calculate that $11 \%(0.03 / 0.28$ $\times 100$ ) of the DOC was vascular plant-derived, a value similar to that calculated from the mixing model.

Results of this study thus suggest that DOM originating in the Crab Cay mangrove swamp is exported offshore at least $1 \mathrm{~km}$, where it accounts for about $10 \%$ of the total DOM. Evidence that this DOM comes primarily from degrading vascular plant material (most likely mangrove detritus) is suggested by lignin phenol concentrations and natural fluorescence properties, both of which are exclusively or primarily associated with vascular plant-derived organic matter. At least some fraction of the exported mangrove swampderived DOM serves as a substrate for bacterioplankton growth and thus may enhance bacterial production in offshore waters.

Acknowledgements. We thank Edward Sheppard, Dianna Johnson, and Georgia Zeigler for expert laboratory and field technical assistance. This research was funded by grant OCE87 18019 from the National Science Foundation and grant NA88AA-D-SG098 from the NOAA Office of Sea Grant

\section{LITERATURE CITED}

Aiken, G. (1985). Isolation and concentration techniques for aquatic humic substances. In: Aiken, G. R., McKnight, D. M., Wershaw, R. L., MacCarthy, P. (eds.) Humic substances in soil, sediment and water. Wiley, Chichester, p. 363-385

Alongi, D. M., Boto, K. G., Tirendi, F. (1989). Effect of exported mangrove litter on bacterial productivity and dissolved organic carbon fluxes in adjacent tropical nearshore sediments. Mar. Ecol. Prog. Ser. 56: 133-144

Azam, F., Fenchel, T., Field, J. G., Gray, J. S., Meyer-Reil, L.A., Thingstad, F. (1983). The ecological role of microbes in the sea. Mar Ecol. Prog. Ser. 10: 257-263

Bratbak, G., Dundas, I. (1984). Bacterial dry matter content and biomass estimations. Appl environ. Microbiol 48: 755-757

Cabaniss, S. E., Shuman, M. S. (1987). Synchronous fluorescence spectra of natural waters: tracing sources of dissolved organic matter. Mar. Chem. 21. 37-50

Coble, R. G., Green, S. A., Blough, N. V., Gagosian, R. B. (1990). Characterization of dissolved organic matter in the Black Sea by fluorescence spectroscopy. Nature, Lond. 348: 432-435

Duursma, E. K. (1974). The fluorescence of dissolved organic matter in the sea. In: Jerlov, N. G., Steeman-Nelson, E. (eds.) Optical aspects of oceanography. Academic Press, London, p. 237-256
Ertel, J. R., Hedges, J. I., Perdue, E. M. (1984). Lignin signature of aquatic humic substances. Science 223: 485-487

Flores-Verdugo, F. J., Day, J. W., Briseño-Dueñas, R. (1987). Structure, litter fall, decomposition, and detritus dynamics of mangroves in a Mexican coastal lagoon with an ephemeral inlet. Mar Ecol. Prog. Ser 35: 83-90

Hedges, J. I., Ertel, J.R. (1982). Characterization of lignin by gas capillary chromatography of cupric oxide oxidation products. Analyt. Chem. 54: 174-178

Hedges, J. I., Parker, P. L. (1976). Land-derived organic matter in surface sediments from the Gulf of Mexico. Geochim. cosmochim. Acta 40:1019-1029

Hedges, J. I., Clark, W. A., Cowie, G. L. (1988). Organic matter sources to the water column and surficial sediments of $a$ marine bay. Limnol. Oceanogr. 33: 1116-1136

Hobbie, J. E., Daley, R. J., Jasper, S. (1977). Use of Nuclepore filters for counting bacteria by epifluorescence microscopy. Appl environ. Microbiol. 33: 1225-1228

Hopkinson, C. S. (1985). Shallow-water benthic and pelagic metabolism: evidence of heterotrophy in the nearshore Georgia Bight. Mar Biol. 87: 19-32

Kalle, K. (1963). Über das Verhalten und die Herkunft der in den Gewässern und in der Atmosphäre vorhandenen himmelblauen Fluoreszenz. Dtsch. Hydrogr. Z. 16: 153-166

Kirchman, D. L., Newell, S. Y., Hodson, R. E. (1986). Incorporation versus biosynthesis of leucine: implications for measuring rates of protein synthesis and biomass production by bacteria in marine systems. Mar Ecol. Prog. Ser 32: $47-59$

Kirchman, D. L., Hoch, M. P. (1988). Bacterial production in the Delaware Bay estuary estimated from thymidine and leucine incorporation rates. Mar Ecol. Prog. Ser 45: $169-178$

Laane, R. W. P. M., Koole, L. (1982). The relation between fluorescence and dissolved organic carbon in the EmsDollart estuary and the western Wadden Sea. Neth. J. Sea Res. 15: 217-227

Larson, R. A., Rockwell, A. L. (1980). Fluorescence spectra of water-soluble humic materials and some potential precursors. Arch. Hydrobiol. 89: 416-425

Lugo, A. E., Snedaker, S. C. (1974). The ecology of mangroves. A. Rev. Ecol. Syst. 5: 39-64

Mann, K. H. (1982). Ecology of coastal waters. Studies in Ecology, Volume 8. Univ. of California Press, Berkeley

Meyers-Schulte, K. J., Hedges, J. I. (1986). Molecular evidence for a terrestrial component of organic matter dissolved in ocean water. Nature, Lond. 321:61-63

Moran, M. A., Hodson, R. E. (1989). Bacterial secondary production on vascular plant detritus: relationships to detritus composition and degradation rate. Appl environ. Microbiol. 55: 2178-2189

Moran, M. A., Hodson, R. E. (1990a). Bacterial production on humic and nonhumic components of dissolved organic carbon. Limnol. Oceanogr. 35: 1744-1756

Moran, M. A., Hodson, R. E. (1990b). Contributions of degrading Spartina alterniflora lignocellulose to the dissolved organic carbon pool of a salt marsh. Mar Ecol. Prog. Ser. 62: $161-168$

Moran, M. A., Pomeroy, L. R., Sheppard, E. S., Atkinson, L. P., Hodson, R. E. (1991). Distribution of terrestrially-derived dissolved organic matter on the southeastern U.S. continental shelf. Limnol. Oceanogr., in press.

Odum, W. E., Heald, E. J. (1975). The detritus-based food web of an estuarine mangrove community. In: Cronin, L. E. (ed.) Estuarine research, Vol. I. Academic Press, New York, p. 265-286

Otto, L. (1967). Investigations on optical properties and water- 
masses of the southern North Sea. Neth. J. Sea Res. 3: $532-551$

Peterson, B. J., Howarth, R. W (1987). Sulfur, carbon, and nitrogen isotopes used to trace organic matter flow in the salt-marsh estuaries of Sapelo Island, Georgia. Limnol. Oceanogr. 32: 1195-1213

Pomeroy, L. R., Wiegert, R. G. (1981). The ecology of a salt marsh. Springer-Verlag, New York

Riemann, B., Bjornsen, P. K., Newell, S., Fallon, R. (1987). Calculation of cell production of coastal marine bacteria based on measured incorporation of $\left[{ }^{3} \mathrm{H}\right]$ thymidine. Limnol. Oceanogr. 32: 471-476

Sarkanen, K. B., Ludwig, C. H. (1971). Lignins. Wiley, Chichester

Teal, J. M. (1962). Energy flow in the salt marsh ecosystem of Georgia. Ecology 41.614-624

Thurman, E. M. (1985). Organic geochemistry of natural waters. Nijhoff/Junk, Dordrecht.

Traganza, E. D. (1969). Fluorescence excitation and emission

This article was submitted to the editor spectra of dissolved organic matter in sea water. Bull. mar. Sci. 19: 897-904

Twilley, R. R. (1985). The exchange of organic carbon in basin mangrove forests in a southwest Florida estuary. Estuar. coast. Shelf Sci. 20: $543-557$

Wicks, R. J., Robarts, R. D. (1988). Ethanol extraction requirement for purification of protein labeled with $\left[{ }^{3} \mathrm{H}\right]$ leucine in aquatic bacterial production studies. Appl. environ. Microbiol. 54: 3191-3193

Willey, J. D. (1984). The effect of seawater magnesium on natural fluorescence during estuarine mixing and implications for tracer applications. Mar. Chem. 15: 19-45

Willey, J. D., Atkinson, L. P. (1982). Natural fluorescence as a tracer for distinguishing between Piedmont and Coastal Plain river water in the nearshore waters of Georgia and North Carolina. Estuar. coast. Shelf Sci. 14: 49-59

Zimmerman, J. T F., Rommets, J. W. (1974). Natural fluorescence as a tracer in the Dutch Wadden Sea and the adjacent North Sea. Neth. J. Sea Res. 8: 117-125

Manuscript first received: March 22, 1991

Revised version accepted: July 19, 1991 